\title{
Insulin and cardiovascular risk factors in newly diagnosed diabetes mellitus patients
}

Wilfried Herdin Sibuea, Suzanna Ndraha

\begin{abstract}
Abstrak
Tujuan penelitian ini ialah untuk meneliti adanya hiperinsulinemia dan faktor risiko kardiovaskuler pada kelompok DMTTI yang baru terdiagnosis dibandingkan dengan kelompok kontrol. Sebanyak 60 subyek yang terdiri dari 30 orang penderita DMTTI yang baru terdiagnosis dan 30 orang sehat ikut dalam penelitian ini. Kelompok penderita DMTTI yang baru terdiagnosis dan kelompok kontrol mempunyai umur, jenis kelamin dan indeks massa tubuh yang sebanding. Pada kedua kelompok diukur iekanan darah sistolik, diastolik dan rasio pinggang-bokong. Dilakukan tes toleransi glukosa oral(TTGO) untuk menilai respons insulin terhadap glukosa. Darah vena diambil saat puasa untuk menilai kadar insulin, glukosa, trigliserida, kolesterol total, kolesterol HDL dan kolesterol LDL. Terdapat beberapa perbedaan yang bermakna antara penderita DMTTI baru dan kelompok kontrol. Tekanan sistolik, kadar glukosa plasma, HbAlc, trigliserida, kolesterol total dan kolesterol LDL lebih tinggi, namun pada waktu TTGO kadar insulin maupun rasio insulin dengan glukosa pada menit ke-30 dan menit ke-120 lebih rendah pada kelompok DMTTI.

Disimpulkan bahwa pada DMTTI yang baru terdiagnosis didapatkan defisiensi insulin dan ditemukan juga faktor risiko kardiovaskuler yaitu hipertensi sistolik, trigliserida, kolesterol total dan kolesterol LDL, tetapi tidak ditemukan korelasi antara insulin dengan faktor risiko kardiovaskuler tersebut.
\end{abstract}

\begin{abstract}
The purpose of this study is to assess the insulin resistance and cardiovascular risk factors in newly diagnosed NIDDM compared with normal control subjects. Thirty subjects with newly diagnosed NIDDM and 30 healthy control subjects, with no family history of NIDDM, matched for age, gender and body mass index participated in this study. Oral glucose tolerance test was performed to measure the insulin response to oral glucose. In both groups, waist to hip ratio, systolic and diastolic blood pressure were measured. Venous blood samples were taken at fasting for insulin, glucose, HbAlc, triglyceride, total cholesterol, LDL cholesterol and HDL cholesterol determinations. Several characteristics of metabolic abnormalities distinguished the newly diagnosed NIDDM from control subjects. The type-2 diabetes subjects had significantly higher systolic blood pressure, plasma glucose, glycosilated hemoglobin, triglyceride, total cholesterol and LDL cholesterol levels compared with controls, but during OGTT, the insulin levels and insulin to glucose ratio at 30-min and 120-min were lower in newly diabetes subjects. In this study we found the presence of insulin deficiency and cardiovascular risk factors such as higher systolic blood pressure, hypertriglyceridemia, hypercholesterolemia in newly diagnosed NIDDM but there was no correlation between insulin with those risk factors.
\end{abstract}

Keywords: Insulin, newly diagnosed NIDDM, cardiovascular risk factors

\section{INTRODUCTION}

Subjects with type II diabetes have a two or fourfold increase risk of developing cardiovascular disease., In type II diabetes, degree of hyperglycemia and duration of clinical diabetes have been strong and consistent risk factors for microvascular complication of diabetes, ${ }^{3,4}$ while cardiovascular disease has often not been associated with these factors.

Department of Internal Medicine, Faculty of Medicine, University of Indonesia, Dr. Cipto Mangunkusumo Hospital Jakarta, Indonesia
In the World Health Organization study the combination of total cholesterol, triglyceride and blood pressure levels was associated with myocardial infarction in diabetes, ${ }^{3}$ and both high triglyceride and low HDL cholesterol levels predicted coronary heart disease, ${ }^{5}$ while central obesity expressed by the $\mathrm{W} / \mathrm{H}$ ratio is itself an independent risk factor for coronary artery disease. $^{6}$

Hyperinsulinemia predictive of the development of type II diabetes, in some studies have been shown to be predictive of coronary heart disease development. ${ }^{7}$ Reaven has proposed that insulin resistance may underlie a number of disorders including hypertension, 
dy slipidemia, impaired glucose tolerance and coronary heart disease, which he called "Syndrome X".

The purpose of this study was to study the insulin concentrations during the Oral Glucose Tolerance Test (OGTT) in newly diagnosed type II diabetes and then to assess the correlation between known cardiovascular risk factors with insulin.

\section{METHOD}

Thirty subjects with newly diagnosed NIDDM and 30 healthy control subjects with no family history of NIDDM, matched for age, gender and body mass index participated in this study. At the time of recruitment, no subjects received medications known to affect glucose metabolism. Body weight was measured to the nearest $0.1 \mathrm{~kg}$ and height to the nearest $0.1 \mathrm{~cm}$ with the head parallel to the floor. Body mass index was calculated as the ratio of weight $(\mathrm{kg})$ to the square of height $\left(\mathrm{m}^{2}\right)$. Waist circumference was measured as the smallest circumference between the costal margin and the iliac crest. Hip measurements were made at the level of the most lateral point on the great trochanter. Minimum waist and maximum hip measurements were taken to calculate the waist to hip (W/H) ratio. ${ }^{9}$

Systolic and diastolic blood pressure using sphygmomanometer were measured by a single observer on 2 occasions after $30 \mathrm{~min}$ of resting. The mean of these values is given $(\mathrm{mmHg})$.

\section{Blood sampling}

A 75 gram oral glucose tolerance test (OGTT) was performed to assess glucose tolerance and to measure the insulin response to oral glucose. After a 12 hour overnight fast, all subjects were given a 75 -g oral glucose load. Venous blood samples were taken at fasting, $30 \mathrm{~min}$ and 120 minutes after the glucose administration for determination of plasma glucose and serum insulin concentrations. Glucose tolerance was interpreted according to WHO criteria. ${ }^{10}$ Yallow and Berson defined insulin resistance as a state of a body in which greater-than-normal amounts of insulin are required to elicit a quantitatively normal response. Insulin resistance was determined by the method of Yallow and Berson with modification. The ratio of plasma insulin to plasma glucose (fasting $\mathrm{I} / \mathrm{G}, 30$-min V/G and 120-min L/G) was calculated in each group and was interpreted as the higher the ratio the greater the insulin resistance. ${ }^{11,12}$
Glycosilated hemoglobin (HbAlc), total cholesterol, HDL cholesterol, LDL cholesterol, and triglyceride were measured on fasting samples.

\section{Laboratory determinations}

Plasma glucose was assayed with a glucose oxidase method (GOD PAP). HbA1c was measured with an enzymatic ion-captured method (normal range 3\%$6.4 \%)$. Total cholesterol, HDL cholesterol, and triglyceride were measured with a calorimetric enzymatic method (CHOD/PAP). LDL cholesterol was calculated with Friedwald formula. Plasma insulin concentration was measured using DPC reagents CoatA-Count according to standard Radioimmunoassay procedure ${ }^{13}$ performed by Research Center for Medical Science and Technology, School of Medicine, University of Indonesia, WHO Laboratory no. 104 for Matched Reagent Programme and no. 21 Zone B for External Quality Control.

\section{Statistical Analysis}

Mean SD is given for normally distributed variables and matched groups are compared by pair- $t$ test. For skewed data, the median [range] is given; Wilcoxon rank test for matched groups and Mann Whitney U test for unmatched groups were used to compare the groups. Linear regression was used to assess the correlation of two variable. All statistical analysis were performed by using SPSS for windows.

\section{RESULTS}

A total of 60 persons were studied : 30 subjects with newly diagnosed NIDDM and 30 healthy control subjects with no family history of NIDDM.

Table 1 shows the clinical details and baseline biochemical data in the 2 groups of subjects. Although the groups were well matched in terms of age, sex and BMI, but surprisingly the subjects with type- 2 diabetes had a similar W/H ratio with the normal control subjects. The type-2 diabetes group had significantly higher systolic blood pressure, triglyceride, total cholesterol and LDL cholesterol levels than controls.

Table 2 and Figure 1 show the glucose and insulin concentrations during the OGTT. There was a significant increase of fasting, 30-min and 120-min glucose concentrations from control to diabetes subjects. Fasting insulin levels were similar $(15.3 \mathrm{mU} / \mathrm{L}$ $8.1 \mathrm{mU} / \mathrm{L}$ vs $11.8 \mathrm{mU} / \mathrm{L} 6.8 \mathrm{mU} / \mathrm{L}, \mathrm{p}=0.07)$. But there was a progressive reduction in $30-\mathrm{min}$ insulin and 
Table 1. Clinical details and baseline biochemical data of the Study Subjects

\begin{tabular}{llll}
\hline Characteristic & $\begin{array}{l}\text { Newly diagnosed } \\
\text { NIDDM }\end{array}$ & Control subjects & $p$ \\
& & \\
\hline No. subjects & 30 & 30 & 1 \\
Gender & $22 \mathrm{M}, 8 \mathrm{~F}$ & F22M,8F & 1 \\
Age (years) & $50.6 \pm .4$ & $49.6 \pm 8.3$ & 0.6 \\
BMI & $26.9 \pm 3.6$ & $25.5 \pm 5.9$ & 0.5 \\
W/H ratio & $0.9 \pm 0.06$ & $0.89 \pm 0.09$ & 0.04 \\
Systolic BP (mmHg) & $131 \pm 20.7$ & $123.2 \pm 13.4$ & 0.38 \\
Diastolic BP(mmHg) & $84 \pm 10.7$ & $82.3 \pm 7.3$ & 0.0001 \\
HbAlc $(\%)$ & $10.5 \pm 4.9$ & $5.5 \pm 0.9$ & 0.02 \\
Total cholesterol (mg/dl) & $231.8 \pm 55.8$ & $203.8 \pm 34.6$ & 0.03 \\
Triglyceride(mg/dl) & $203.5[108-940]$ & $156.5[48-559]$ & 0.87 \\
HDL cholesterol (mg/dl) & $49.9 \pm 12.3$ & $49.4 \pm 11.6$ & 0.04 \\
LDL cholesterol (mg/dl) & $173.1 \pm 44.6$ & $148.1 \pm 47.5$ & \\
\hline
\end{tabular}

120-min insulin concentrations from control to diabetes subjects.

To clarify the presence of insulin resistance in diabetes subjects, the ratios of plasma insulin and glucose were calculated.

As shown in Figure 2, the $\mathrm{I} / \mathrm{G}$ ratios were lower (Fast-
$\mathrm{U}$. As the fasting glucose increases from $80 \mathrm{mg} / \mathrm{dl}$ to $140 \mathrm{mg} / \mathrm{dl}$ there is a progressive rise in fasting insulin, representing a compensatory response by the pancreas. When the fasting glucose exceed $140 \mathrm{mg} / \mathrm{dl}$, insulin secretion drops because the pancreas is unable to maintain high rate insulin secretion. In diabetic subjects with fasting glucose concentrations $>200 \mathrm{mg} / \mathrm{dl}$, the

Table 2: The glucose and insulin concentrations during the OGTT

\begin{tabular}{llll}
\hline Characteristic & $\begin{array}{l}\text { Newly diagnosed } \\
\text { NIDDM }\end{array}$ & Control subjects & $p$ \\
\hline Fasting plasma glucose $(\mathrm{mg} / \mathrm{dl})$ & $199.4 \pm 72$ & $91 \pm 12.1$ & 0.0001 \\
30 min plasma glucose(mg/dl) & $278.3 \pm 87$ & $151.9 \pm 28.5$ & 0.0001 \\
120 min plasma glucose(mg/dl) & $317.4 \pm 94$ & $128.4 \pm 33.8$ & 0.0001 \\
Fasting plasma insulin(mU/L) & $15.3 \pm 8.1$ & $11.8 \pm 6.8$ & 0.07 \\
30 min plasma insulin(mU/L) & $42.2 \pm 51$ & $80.8 \pm 49.6$ & 0.04 \\
120 min plasma insulin(mU/L) & $52.6 \pm 39.3$ & $84.4 \pm 53.3$ & 0.01 \\
\hline
\end{tabular}

ing $\mathrm{J} / \mathrm{G} 0.08$ vs $0.12 ; 30$ - $\mathrm{min} \mathrm{V} / \mathrm{G} 0.15$ vs $0.5 ; 120$-min $\mathrm{I} / \mathrm{G} 0.16$ vs 0.6 ; total $\mathrm{I} / \mathrm{G} 0.2$ vs 0.45 ) in newly diagnosed NIDDM than in normal control subjects. It meant that in diabetic subjects, there was no insulin resistance.

Table 3 shows the correlation of insulin and cardiovascular risk factors. The insulin levels do not correlate with $\mathrm{W} / \mathrm{H}$ ratio, systolic blood pressure, triglyceride, total cholesterol as well as LDL cholesterol.

\section{DISCUSSION}

According to De Fronzo, the relationship between fasting glucose and insulin levels resembled an inverted insulin level declines to values observed in control subjects. ${ }^{14}$ The current study confirms that subjects with type- 2 diabetes well matched for age, sex and

Table 3. Correlation between insulin and cardiovascular risk factors

\begin{tabular}{lcl}
\hline & $\mathrm{r}$ & $p$ \\
\hline Insulin and W/H ratio & 0.08 & 0.5 \\
Insulin and systolic blood pressure & 0.18 & 0.2 \\
Insulin and triglyceride & 0.04 & 0.7 \\
Insulin and total cholesterol & 10.17 & 0.2 \\
Insulin and LDL cholesterol & 10.23 & 0.07 \\
\hline
\end{tabular}




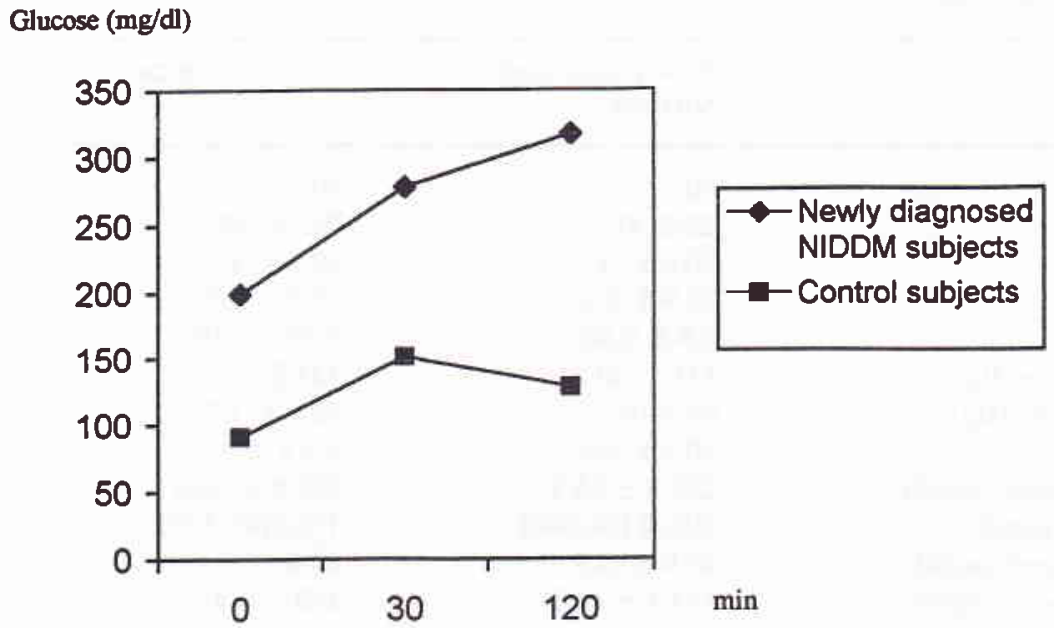

Figure la. Glucose levels during the OGTT

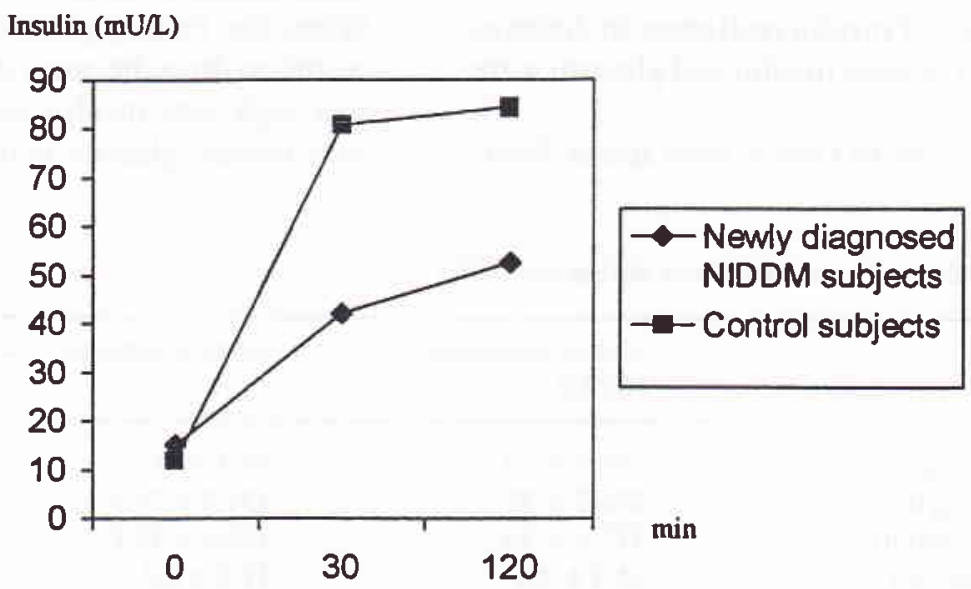

Figure $1 b$. Insulin levels during the OGTT

BMI, have similar fasting insulin concentrations with normal control subjects. However, as diabetic subjects had significantly higher fasting glucose concentration, their 'normal' fasting insulin levels could be regarded as inability of pancreas to compensate the deterioration in glucose metabolism.

After a glucose load, the insulin concentrations decreased remarkably in the diabetic subjects who had fasting hyperglycemia $(199,4 \mathrm{mg} / \mathrm{dl})$. In addition as shown in figure 2 , there was no insulin resistance in diabetic subjects because the insulin-glucose ratios were lower compared to normal controls. By these results we presumed that the type- 2 diabetes subjects was insulinopenic. These findings are consistent with the earlier study and explained by the Starling's curve of the pancreas as proposed by de Fronzo. In diabetic subjects the relation of plasma insulin response to ingestion of glucose is like inverted U-shaped curve where plasma insulin increases progressively until the fasting plasma glucose reaches $120 \mathrm{mg} / \mathrm{dl}$. Thereafter, further increases in the fasting plasma glucose level concentrations to $>160 \mathrm{mg} / \mathrm{dl}$, the plasma insulin response becomes insulinopenic. ${ }^{15}$

The 30-min insulin concentration was lower in diabetic subjects than in normal controls. Normally, pancreatic beta cells respond rapidly to secrete insulin 3-5 min after glucose injection during an intravenous glucose tolerance test (IVGTT) and lasts about 10 minutes. 


\section{I/G ratio}

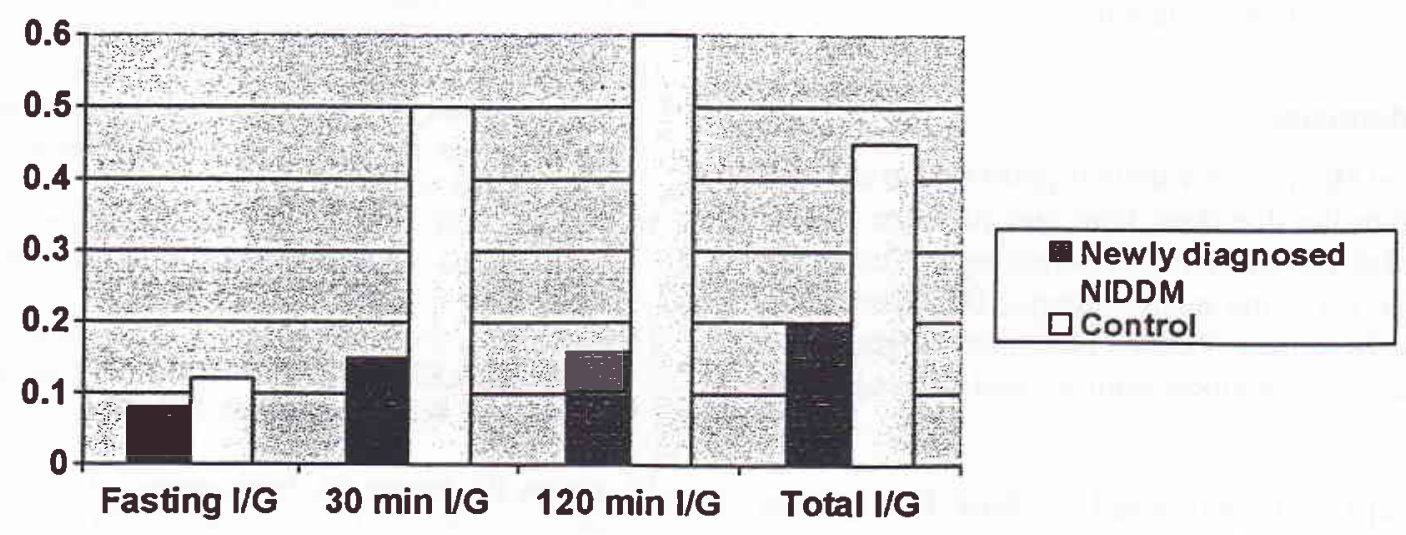

Figure 2. Insulin resistance ( $/ / G$ ratio) between newly diagnosed NIDDM and control

This is called acute insulin release (AIR). Some authors said that the 30-min insulin concentration during OGTT is similar with the AIR during IVGTT. This suggests that in the absence of IVGTT, this measurement may give the best estimate of changes in the first phase of insulin secretion. ${ }^{12,14}$ In diabetic subjects the early phase of insulin secretion during both IVGTT and OGTT is reduced due to the lost of acute insulin release. ${ }^{11,12,16}$ We found the same result in this current study.

From these results (inability of pancreas to compensate the deterioration in glucose metabolism, insulinopenia and reduced early phase of insulin secretion), it would be presumed that beta cells dysfunction and insulin deficiency are major features of type- 2 diabetes in this study.

Increased mortality from cardiovascular disease is seen in subjects with type-2 diabetes due to the macrovascular complications. In the World Health Organization (WHO) study, the combination of high cholesterol, high triglyceride and blood pressure levels was associated with higher prevalence of myocardial infarction in diabetics. ${ }^{6}$ In the Paris Prospective study, high triglyceride levels predicted the development of coronary heart disease ${ }^{17}$; and in the East West Study in Finland, both high triglyceride and low HDL cholesterol predicted the development of coronary heart disease.? In the current study we found a significant higher systolic blood pressure, triglyceride, total cholesterol and LDL cholesterol levels. These findings showed that in newly diabetes subjects cardiovascular risk factors were already present.
The insulin resistance was determined indirectly in this study. The gold standard for insulin resistance determination is euglycemic clamp technique in which insulin is infused systemically and plasma glucose is maintain constant by exogenous glucose infusion. Glucose is clamped at euglycemia level. Glucose infusion rate equals some of decrease in hepatic glucose release and increase in glucose uptake ${ }^{19}$. By this method, Ndraha found higher insulin resistance in the overweight Indonesian NIDDM subjects and there was a significant correlation between BMI and fasting insulin level. ${ }^{20}$ In this study we didn't perform euglycemic clamp technique because of the expense, but determined the insulin resistance by using I/G ratio. 11,12

According to the San Antonio Heart Study, increase of fasting insulin level significantly predicted the development of type-2 diabetes, low HDL cholesterol, high triglyceride levels and hypertension over an 8 years follow-up. ${ }^{18}$ Reaven suggested that insulin resistance may underlie hypertension, high triglyceride, low HDL cholesterol, impaired glucose tolerance and coronary heart disease. ${ }^{8}$ In this study, we could not find the correlation between insulin and various conventional coronary heart disease risk factors such as W/H ratio, systolic blood pressure, high triglyceride, total cholesterol and LDL cholesterol levels due to the absence of fasting hyperinsulinemia and insulin resistance.

The lack of hyperinsulinemia in this study does not exclude the presence of hyperinsulinemia prior to the development of type- 2 diabetes. As many years of 
hyperinsulinemia characterize the prediabetic stage ${ }^{21}$, it is still possible that during these years coronary heart disease risk factors developed.

\section{Acknowledgments}

I thank Tebet Hospital for their support and grant, and the study families for their kind and patience. I also thank the Makmal Immunoendocrinology, University of Indonesia, for doing insulin assays; Dr. Diana, Dra. med Dewi, Drs. med Ventje, Drs. med Sugeng and nurses for collecting blood samples and inviting study families.

Special thanks are extended to Prof Dr. Slamet Suyono, Internist, Endocrinologist, head of subdivision of Metabolism and Endocrinology, Department of Internal Medicine, Faculty of Medicine, University of Indonesia for his supports and advises.

\section{REFERENCES}

1. Gracia MJ, McNamara PM, Gordon T, Kannel WB. Morbidity and mortality in diabetics in the Framingham population: sixteen-year follow-up. Diabetes 1974;23:105-11

2. Stamler J, Vaccaro O, Neaton JD, Wenworth D. Multiple riak factor intervention trial research group. Diabetes, other risk factors and 12-year cardiovascular mortality for men screened in the multiple risk factor interventional trial. Diabetes Care 1993;16:434-44

3. Diabetes Drafting Group. Prevalence of small vessel and large vessel disease in diabetic patients from 14 centres: the World Health Organization Multinational Study of vascular disease in diabetic. Diabetologia 1985;28:615-40

4. Klein R, Klein BEK, Moss E, Davis MD, DeMets DL, Glycosilated haemoglobine predicts the incidence and progression of diabetics retinopathy. JAMA 1988;260:286471

5. Laakso M, Letho S, Pettila I, Pyorala K. Lipids and lipoprotein predicting coronary heart disease mortality and morbidity in patients with non-insulin dependent diabetes. Circulation 1993;88:1421-30

6. Haffner SM, Valdez RA, Hazuda HP, Mitchell BD, Morales PA, Stern MP. Prospective analyses of the insulin resistance syndrome (syndrome X). Diabetes 1992;41:715-22

7. Haffner SM, Stern MP, Hazuda HP, Pugh JA, Patterson JK. Hyperinsulinemia in a population at high risk for non-in- sulin-dependent diabetes mellitus. N Engl J Med 1986;315:220-4

8. Reaven GM. Banting Lecture: role of insulin resistance in human disease. Diabetes 1988;37:1595-607

9. Knight TM, Smith Z, Whittles A, Sahota P. Insulin resistance, diabetes, and risk markers for ischaemic heart disease in Asian men and non-Asian men in Bradford. Br Heart $\mathrm{J}$ 1992;67:343-50

10. Prevention of Diabetes Mellitus. Report of WHO study group. WHO Technical Report Series,No. 844; Geneva, 1994

11. Berson SA, Yallow RS. Insulin 'antagonist' and insulin resistance. In Ellenberg M, Rifkin H (eds). Diabetes mellitus: Theory and Practice. McGraw-Hill, New York 1970:388423

12. Yallow RS, Berson SA. Immunoassay of endogenous plasma insulin in man. J Clin Invest 1960;39:1157-75

13. Tsu T, Herzenberg LA. Solid phase radioimmune assays. In Mishell, Shiigi SM (eds). Selected Methods in Cellular Immunology. Freeman and Co. San Francisco 1980:373-97

14. De Fronzo RA, Bonadonna RC, Ferrarini E. Pathogenesis of NIDDM. A balanced overview. Diab Care 1992;15(3);31868

15. De Fronzo RA. Lily Lecture 1987: The Triumvirate: cell, muscle, liver. A collusion responsible for NIDDM. Diabetes 1988;37:667-87

16. Davies MJ, Metcalfe J, Gray IP, Day JL, Hales CN. Insulin deficiency rather than hyperinsulinemia in newly diagnosed type-2 diabetes mellitus. Diab Med 1993;10:305-12

17. Fontbonne A, Escwege E, Cambein F. Hypertriglyceridemia as a risk factor of coronary heart disease mortality in subjects with impaired glucose tolerance or diabetes: results from a 11 year follow-up of the Paris Prospective study. Diabetologia 32:300-4

18. Morales PA, Mitchell BD, Valdez RS, Hazuda HP, Stem MP, Haffner SM. Incidence of NIDDM and impaired glucose tolerance in hypertensive subjects; the Sarı Antonio Heart Study. Diabetes 1993;42:154-61

19. De Fronzo RA, Tobin JD, Andres R. Glucose Clamp Technique: a method for qualifying insulin secretion and resistance. Am J Physiol 1979;273:E214-23

20. Ndraha S, Soewondo P, Suyono S. Resistensi insulin pada diabetes melitus tidak tergantung insulin berat badan lebih. Paper akhir Program Studi Spesialis II bidang Ilmu Penyakit Dalam Jakarta, 1996

21. Haffner SM, Stern MP, Mitchell BD, Hazuda HP, Pattersom JK. Incidence of type-2 diabetes in Mexican Americans predicted by fasting insulin and glucose levels, obesity and body fat distribution. Diabetes 1990;39:283-8 